\begin{tabular}{|c|c|c|}
\hline 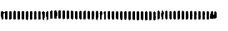 & $U D C$ & $620,186,12$ \\
\hline 論 文 & & $\begin{array}{l}621.785 .3 / 7 \\
620.172 / 178\end{array}$ \\
\hline
\end{tabular}

\title{
2 相ステンレス鋼の熱処理による機械的性質の変化*
}

\author{
星野 明彦**.金尾 正雄*** 中中野 恵司** \\ Variation of Mechanical Properties with Heat Treatment of Two \\ Phase Stainless Steel
}

Akihiko Hoshino, Masao Kanao, and Keishi Nakano

Synopsis:

The effect of heat treatment on the mechanical properties of $\mathrm{Fe}-25 \mathrm{Cr}-6 \mathrm{Ni}$ alloy has been investigated, and the results are summarized as follows.

(1) In case of aging at $475-525^{\circ} \mathrm{C}$, the tensile strength and $0.2 \%$ proof srtess increase continuously with aging time owing to the precipitation of $\mathrm{Cr}$-rich phase in ferrite matrix. In spite of the decrease in elongation, the reduction of area shows an approximately constant value of $60-70 \%$.

(2) Heating at $650-800^{\circ} \mathrm{C}$ produces the $\alpha-\gamma$ transformation and proof stress decreases with the increase of $\gamma$ content. The tensile strength that is affected by work hardening of $\gamma$ phase during the deformation does not vary in parallel with the proof stress.

(3) Charpy impact value decreases with aging time at $475-525^{\circ} \mathrm{C}$. The testing temperature dependence of the Charpy impact valus is based on the raise in the transition temperature due to the $475^{\circ} \mathrm{C}$ embrittlement.

(4) The prior $\alpha-\gamma$ transformation that produces an increase in $\gamma$ content and an increase of $\mathrm{Cr}$ concentration in $\alpha$ phase leads to the reduction of susceptibility for $475^{\circ} \mathrm{C}$ embrittlement.

(5) It is observed that $\sigma$ phase in two-phase stainless steel is formed by decomposition of high Gr ferrite phase into $\sigma+\gamma$, independently of $\mathrm{Cr}$ carbide.

\section{1. 緒言}

フェライトオーステナイト相よりなる 2 相ステンレ ス鋼は，オーステナイト鋼の欠点である応力腐食割れの 対応策として開発されてきた鋼種である. 2 相ステンレ 不鋼は微細組織を特徵とするので, 強度と鞋性に優れて いる1ほか,フェライト $(\alpha)$ 学 50 ～60\% 含む合金は耐応 力腐食割れにもすぐれていることが鈴木ら2゙によつて報 告されている.

ところが， 2 相ステンレス鋼を溶接もしくは高温焼な まし後徐冷すると脆化しやすく，これが 2 相ステンレス 鋼の製造上での問題点であろう.これは高クロムフェラ イトステンレス鋼に現われる $475^{\circ} \mathrm{C}$ 脆性もしくは $\sigma$ 相 脆性にも関連するが，微細混合組織の 2 相ステンレス鋼 では特に組織変動の現われやすい危険性がある.

そこで，本研究においては 2 相ステンレス鋼の品質不 安定性の要因となる 組織不安定性に 着目し， $25 \mathrm{Cr}-6 \mathrm{Ni}$ 鋼の熱処理に伴う組織变動が機械的性質におよぼす影響
について検討することにした.

\section{2. 供試材および実験方法}

\section{$2 \cdot 1$ 供試材}

電解鉄，電解クロムおよび電解ニッケルを原料として 真空溶解法によつて $\mathrm{Fe}-25 \% \mathrm{Cr}-6 \% \mathrm{Ni}$ 合金の $17 \mathrm{~kg}$ 鋼 塊を溶製した。この合金の溶製においては $\mathrm{Al}$ およ゙ $\mathrm{Ti}$ を脱酸荗こして添加した。この合金の化学分析結果は Table 1 に示すとおりである.

この鋼塊を $1250^{\circ} \mathrm{C} \times 1 \mathrm{~h}$ 均熱後，一部を $13 \mathrm{~mm}$ 角に， 他を $10 \mathrm{~mm} \dot{\phi}$ の棒材にそれぞれ熱間圧延した．前者か らはシャルピー試験片（JIS 4 号）龙作成し，後者から は丸棒引張試験片を作成して実験に供した。

\section{$2 \cdot 2$ 実験方法}

これらの材料をまず $1000^{\circ} \mathrm{C} \times 1 \mathrm{~h}$ 程浴中で焼なまし 後水冷し, 次いで $475^{\circ} \mathrm{C}$ 脆性域の $475 \sim 525^{\circ} \mathrm{C}$, および $\sigma$ 相脆性域の $650 \sim 800^{\circ} \mathrm{C}$ の温度域で再加熱後水冷して から, 組織観察, 衝撃試験および引張試験を行つた. 組

* 昭和50年 4 月本会講演大会にて発表 昭和51年 9 月 7 日受付 (Received Sep. 7，1976)

** 金属材料技術研究所 (National Research Institute for Metals, 2-3-12 Nakameguro Megro-ku Tokyo 153)

*** 金属材料技術研究所工博 (National Reseach Institute for Metals) 
Table 1. Chemical composition of the alloy used (wt \%).

\begin{tabular}{c|c|c|c|c|c|c|c|c|c}
\hline $\mathrm{G}$ & $\mathrm{Cr}$ & $\mathrm{Ni}$ & $\mathrm{Si}$ & $\mathrm{Mn}$ & $\mathrm{S}$ & $\mathrm{P}$ & $\mathrm{Ti}$ & $\mathrm{Al}$ & $\mathrm{N}$ \\
\hline 0.005 & 24.24 & 5.07 & $\mathbf{0 . 0 0 4}$ & 0.005 & 0.013 & 0.004 & 0.027 & 0.008 & 0.0083 \\
\hline
\end{tabular}

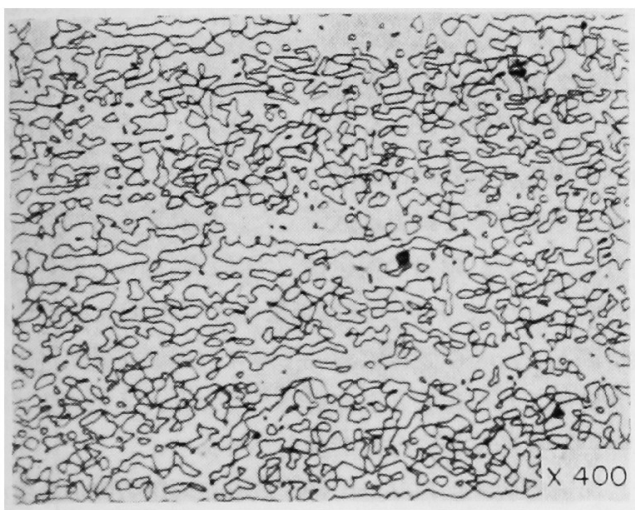

Photo. 1. Microstructure of $\mathrm{Fe}-25 \mathrm{Cr}-6 \mathrm{Ni}$ alloy annealed at $1000^{\circ} \mathrm{C}$. (longitudinal section)

Table 2. Gr and $\mathrm{Ni}$ content in each phase (wt \%).

\begin{tabular}{l|c|c|c|c}
\hline & \multicolumn{2}{|c|}{$1000^{\circ} \mathrm{C} \times 1 \mathrm{~h} \mathrm{WQ}$} & \multicolumn{2}{|c}{$750^{\circ} \mathrm{C} \times 1 \mathrm{~h}$} \\
\cline { 2 - 5 } & $\mathrm{Cr}$ & $\mathrm{Ni}$ & $\mathrm{Cr}$ & $\mathrm{Ni}$ \\
\hline Ferrite $(\alpha)$ & 26.8 & 5.0 & 27.9 & 3.9 \\
Austenite $(r)$ & 19.4 & 9.7 & 19.5 & 9.5 \\
\hline
\end{tabular}

織観察には $10 \%$ 蓚酸水溶液による電解腐食に加えて, フェライト相 $(\alpha)$ とオーステナイト相 $(\gamma)$ の識別のため に改良村上試薬も利用した。 なお，引張試験には $\mathrm{D}=$ $4 \mathrm{~mm} \phi, \mathrm{L}=25 \mathrm{~mm}$ の丸棒試梚を使用し，インストロン 試験機によつて $0.05 \mathrm{~cm} / \min$ のクロスヘッド速度で試 験した。

\section{3. 実験結果および考察}

\section{1 組織変化}

$1000^{\circ} \mathrm{C}$ 焼な屯し水泠材は压延方向に沿つた断面で は，Photo. 1 に示すように若干の方向性が認められた。 この組織を村上試薬によつて識別後, リニアル・アナリ シスによつて $\alpha$ 量を求めると約 $62 \%$ であつた。また $\mathrm{X}$ 線マイクロアナライザによる各相中の $\mathrm{Cr}$ および $\mathrm{Ni} の$ 定量分析結果は Table 2 に示すとおりであつた.

焼なまし材を $600 \sim 900^{\circ} \mathrm{C}$ で再加熱すると $\alpha \rightarrow \gamma$ 变態 が現れることが知られているが3)4，1000 $\mathrm{C}$ 焼なまし 後，例えば $750^{\circ} \mathrm{C} \times 1 \mathrm{~h}$ 再加熱することにより $\alpha$ 量は $52 \%$ に低下し，この場合各相中の $\mathrm{Cr}$ および $\mathrm{Ni}$ 量は Table 2 に示したように，とくに $\alpha$ 相中に合金元素の濃
度変動が認められ，一方 $\gamma$ 相中での濃度変化は少なかつ た。

\section{$3 \cdot 2$ 引張特性}

\section{$3 \cdot 2 \cdot 1475^{\circ} \mathrm{C}$ 脆性域に打ける再加熱}

$475 \sim 525^{\circ} \mathrm{C}$ の温度域で再加熱後水冷した試験片につ いては，Fig. 1 K示卞ように，加熱時間にともなう引張 強さおよび $0.2 \%$ 耐力の上昇が認められた、この強化は $\mathrm{Fe}-\mathrm{Cr}$ 合金の 2 相分離による Gr rich 相の析出反応に よるもので5)，加熱初期より強化現象が現われており， しかも $500^{\circ} \mathrm{C}$ 近傍において反応速度が最大となる.

一方，Fig. 2 は加熱時間にともなう伸びと絞りの変化 を示し，Fig. 1 における強化に対応して伸びは低下し， $500^{\circ} \mathrm{C}$ 付近において 2 相分離反応が最大となることが明 らかとなつた。このように時効時間にともなつて強さの

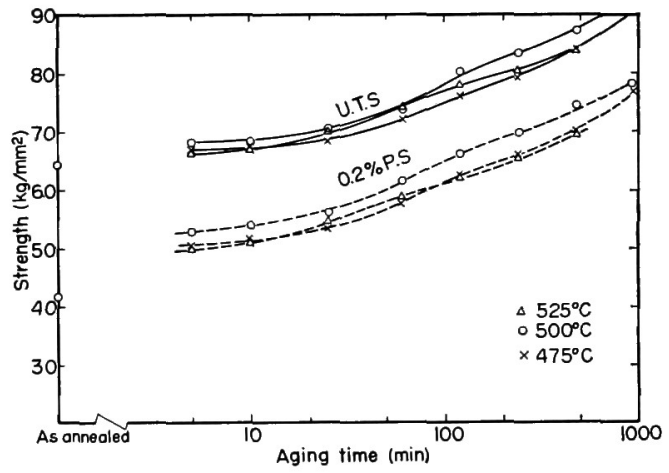

Fig. 1. Variation in strength with aging time at $475-525^{\circ} \mathrm{C}$.

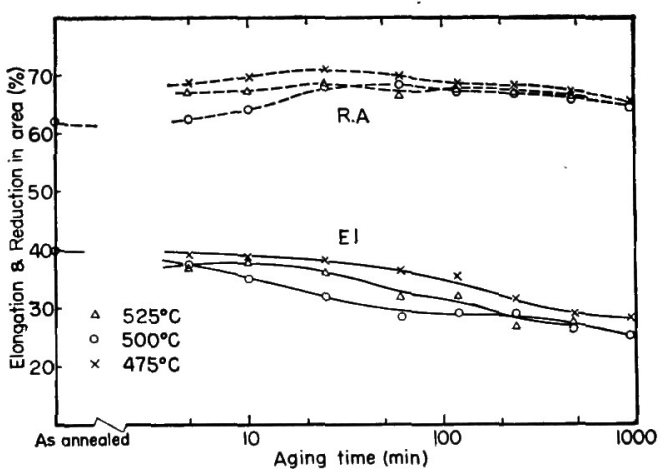

Fig. 2. Variation in tensile ductility with aging time at $475-525^{\circ} \mathrm{C}$. 


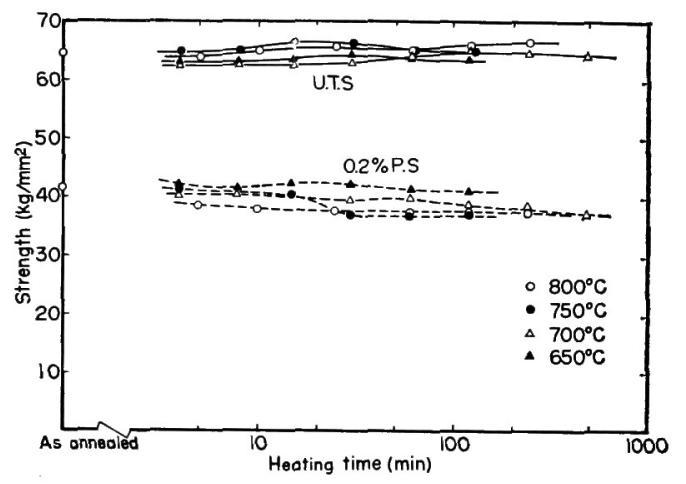

Fig. 3. Variation in strength with heating time at $650-800^{\circ} \mathrm{C}$.

上昇と伸びの低下が現われるけれども，Fig. 2 に示すよ らに絞りは 60〜70\% のほぼ一定の值を示した.

析出硬化鋼の引張特性に関しては, 河部ら ${ }^{6)}$ が $18 \mathrm{Ni}$ マ ルエージ鋼について調べ，時効材の絞りと局部伸びの相 関性を示した. そしてこれらの值は粒度依存性を示す が，ある限られた粒度範囲では時勃にともなう耐力の増 加に対していずれも変化は少なく, 過時効状態になれば 低下することを明らかにしている. 本実騟における 2 相 ステンレス鋼を時効した場合，2相分離領域での析出相 は Cr rich 相であり，Fig. 1 に示した限りにおいては， この合金には過時効現象は現れていない. 結果として, 本合金の時効による耐力の上昇 $\left(40 \rightarrow 80 \mathrm{~kg} / \mathrm{mm}^{2}\right)$ にも かかわらず絞りで変化しなかつたのは, 過時効状態でな いことや粒徍などに基因すると考えられる．また絞りと 局部伸びとの相関性より Fig. 2 に示した伸びの低下は 均一伸びの低下による.

\section{$3 \cdot 2 \cdot 2650 \sim 800^{\circ} \mathrm{C}$ における再加熱}

この温度域で再加熱した場合，加熱時間にともなう引 張強さおよび $0.2 \%$ 耐力の変化は Fig. 3 のとおりであ る. 引張強さは $650,700^{\circ} \mathrm{C}$ で加熱した場合よりも 750 , $800^{\circ} \mathrm{C}$ で加熱した方が高くなり，一方 $0.2 \%$ 耐力は引 張強さとは逆の結果となり, $750,800^{\circ} \mathrm{C}$ で加熱すると 低下した。

このような加熱温度および時間にともなう変化はこの 温度域で現われる $\alpha \rightarrow \gamma$ 变態3)47)基因している.すな わち，この温度域の高温側で加熱するほど $\alpha \rightarrow \gamma$ 变態に より $\gamma$ 量は增加するが, 一方低温域では変態駆動力は大 きくても拡散速度が低下しているので $\gamma$ 量は增加しな い. ところで, 高温側での $\gamma$ 量増加と引張強さの上昇と の関係は, 引張変形中に生ずる $\gamma$ の加工硬化もしくはマ ルテンサイト变態によると考えられている. 本実験のよ うな常温引張試験においては $19 \mathrm{Cr}-9 \mathrm{Ni}$ の組成を有する $\gamma$ 相はかなり安定であり，しかも 2 相ステンレス鋼のよ うに強力な $\alpha$ 相に取囲まれた $\gamma$ 相のマルテンサイト変態 は抑制されるという FLOREEN ${ }^{8)}$ の結果より考虑すれば, $\gamma$ 量の増加による引張強さの上昇はマルテンサイト変態 によるものではなく，単に加工硬化によるものと考光ら れた.

$0.2 \%$ 耐力は $\alpha$ 量に依存するため, 引張強さの変化と は逆に $650,700^{\circ} \mathrm{C}$ の低温側では高く，焼なまし材の耐 力と同程度であるのに対して，高温側での加熱によつて $r$ 量が増加すると耐力注下した. Fig. 3 より明らかな ように， $0.2 \%$ 耐力の変化は $750^{\circ} \mathrm{C}$ において顕著であ つたが，これは 3.1 で述べたように $750^{\circ} \mathrm{C} に$ に打る加 熱時間と $\alpha$ 量との関倸において $1 \mathrm{~h}$ 以内に $\alpha$ 量が平衡近 くまで低下した現象とよく対応しており， 2 相ステンレ 又鋼の耐力の $\alpha$ 量依存性が明らかであつた.

この温度域で加熱した場合，絞りは 60〜 70\% の值を 示し，一方伸びは最初の $1 \mathrm{~h}$ までは焼なむし材と同程度 であるが，1h を超劣ると $650^{\circ} \mathrm{C}$ では高くなり，一方 $800^{\circ} \mathrm{C}$ では低下し，伸びに対する加熱温度の影響が現わ れた。この結果は田村らの゙による $r$ 量と伸びとの関係と 一見矛盾するので，ここでは伸びにおよぼす $\gamma$ 粒経およ び $\alpha$ 相中の Cr 濃度の影響について考察することにした。

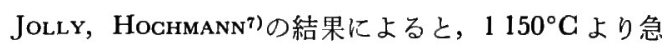
冷した $21 \mathrm{Cr}-8 \mathrm{Ni}$ 型の 2 相合金の $\alpha \rightarrow \gamma$ 变態は $750^{\circ} \mathrm{C}$

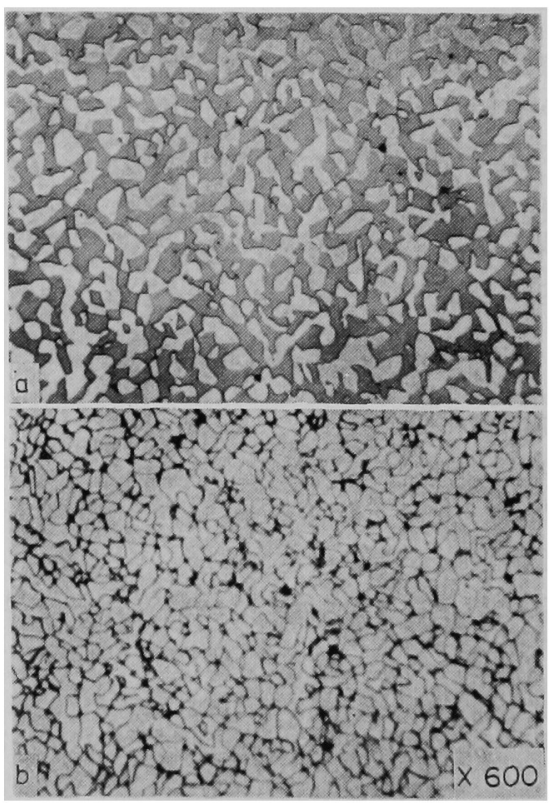

$\begin{array}{ll}\text { (a) } 800^{\circ} \mathrm{C} \times 2 \mathrm{~h}, & \text { (b) } 650^{\circ} \mathrm{C} \times 2 \mathrm{~h}\end{array}$

Photo. 2. Microstructures of alloy reheated at $800^{\circ} \mathrm{C}$ and $650^{\circ} \mathrm{C}$.

(Etched by Murakamr's reagent) 
以上では $\alpha / \gamma$ 界面移動型となり，一方それ以下の温度 では $\alpha$ 相中への $\gamma$ 核生成による微細析出型となることが 明らかにされた，Photo. 2 は本実験に供した合金の 800 ${ }^{\circ} \mathrm{C} \times 2 \mathrm{~h}, 650^{\circ} \mathrm{C} \times 2 \mathrm{~h}$ 加熱材の光学顕微鏡組織であり, $800^{\circ} \mathrm{C}$ 加熱の場合 (Photo, 2a) には $\alpha / \gamma$ 界面移動によ る $\gamma$ 粒径の成長を認めることができた. 一方 $650^{\circ} \mathrm{C}$ 加 㙓試料 (Photo. 2b) においては前者に比較して $r$ 粒は微

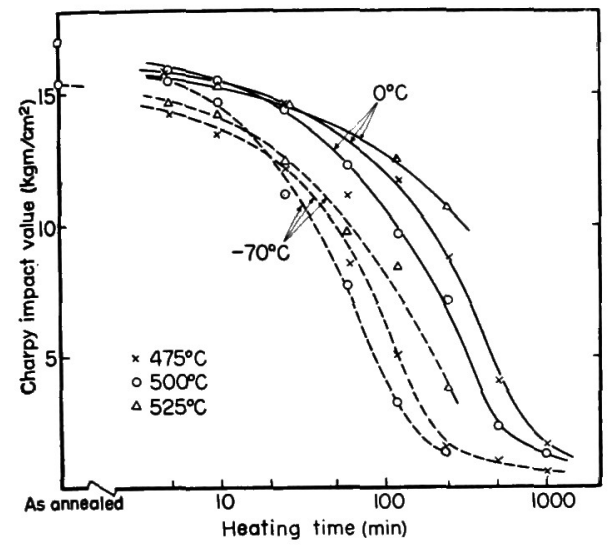

Fig. 4. Variation in notch-toughness with aging time at $475-525^{\circ} \mathrm{C}$.

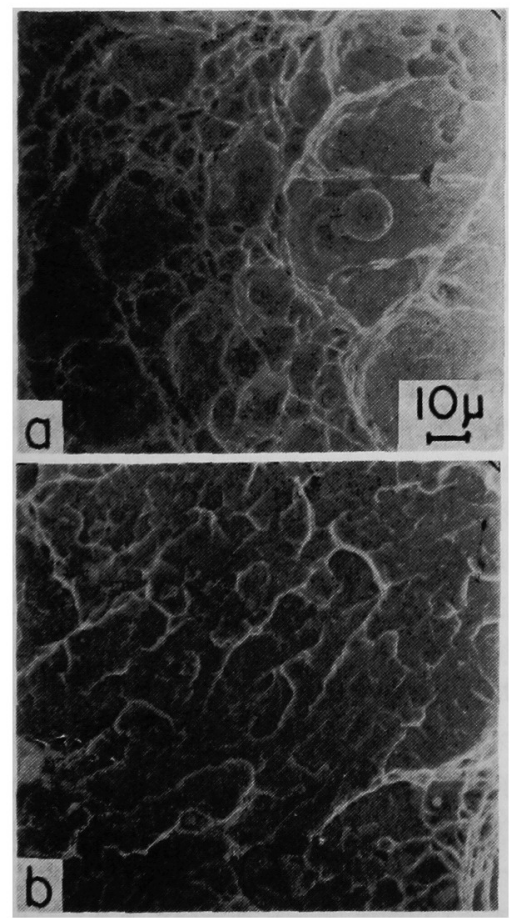

Photo. 3. Microfractographs of Charpy impact test specimens aged at $475^{\circ} \mathrm{C}$. $25 \mathrm{~min}$ (b) $475^{\circ} \mathrm{C} \times 16 \mathrm{~h}$
細であり，焼なまし材と同程度であつた.しかしこの Photo. 2b においてはJoLLOY らが示した $\alpha$ 相中への $\gamma$ 相の微細析出は観察できず，これは焼なまし温度の相異 に基ゔく低温域での変態駆動力の差に基因する.

つぎに Photo. 2a，b を比較した場合，村上試薬によ る $\alpha$ 相の着色度がかなり異なり，これは $\alpha$ 相中の $\mathrm{Cr}$ 濃 度に依存している。 $\alpha$ 相中の Cr 量と伸びとの関係につ

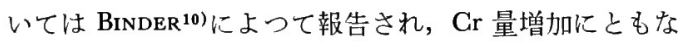
つて伸びが低下することが知られている. 以上の結果よ り本研究における $800^{\circ} \mathrm{G}$ 加熱による伸びの低下は $\gamma$ 粒 径と $\alpha$ 相中への $\mathrm{Cr}$ の濃縮の影響によると考えるのが妥 当と思われる.

\section{3 衝撃特性}

$3 \cdot 3 \cdot 1475^{\circ} \mathrm{C}$ 時効による鞄性の变化

$475 \sim 525^{\circ} \mathrm{C}$ の温度域において時効処理し, 時効温度, 時効時間および試験温度がシャルピー衝撃值におよぼす 影響を Fig. 4 に図示した. 試験温度 $0^{\circ} \mathrm{C}$ の場合, 時 効時間によるシャルピー衝揧值の低下は顕著であるが, ー70 $\mathrm{C}$ においては衝揧値の低下は一層顕著となり,試験

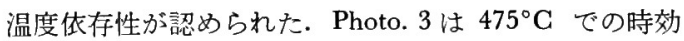
時間にともなう破壊様式の变化を示し, 時効初期には $0^{\circ} \mathrm{C}$ 試験により延性破面を呈し，(Photo. 3a)，ここでは ディンプル底部に非金属介在物が観察される.しかし時 効時間が長くなれば $0^{\circ} \mathrm{G}$ において脆性破壊となり，こ の破面 (Photo. $3 \mathrm{~b}$ ) には介在物の痕跡が見られず，また $\gamma$ 相の延性破壊も認め難くなる. HAYDEN ${ }^{11)}$ は 2 相ステ ンレス鋼の破壊の研究において， $475^{\circ} \mathrm{C}$ 脆性の結果とし て衝慗遷移温度の上昇が生じ, 脆性領域では不連続へき 開破壊が生じることを示した。すなわち， $\alpha$ 相ではへき 開破壊となり，残部の $\gamma$ 相は遷移温度付近ではディンプ ル破壊上なるが，さらに低温側ではせん断破壊となるこ とを明らかとした. Photo. 3bにおいては $\gamma$ 相が局部的 な塑性変形過程であるせん断破壊によつて破断したと考 えられ，この場合にはディンプル破壊におけるほど塑性 変形量は大きくなく，吸収エネルギは著しく低下する.

$3 \cdot 3 \cdot 2650 \sim 800^{\circ} \mathrm{C}$ 再加熱による鞋性の変化

この温度域で再加熱した場合，実験した範囲内では吸 収エネルギは加熱温度および時間によつて变動せず，こ の温度域で現れる $\alpha \rightarrow \gamma$ 变態は切欠䩖性に余り影響をお よぼさなかつた。

\section{$3 \cdot 3 \cdot 3$ 実用鋼における脆化挙動との比較}

実用 2 相ステンレス鋼である $3 \mathrm{RE} 60(0.03 \% \mathrm{C}, 18.5$ $\% \mathrm{Cr}, 4.7 \% \mathrm{Ni}, 1.7 \% \mathrm{Si}, 2.7 \% \mathrm{Mo})$ および AISI 329 $(0.08 \% \mathrm{C}, 23 \sim 28 \% \mathrm{Cr}, 5 \% \mathrm{Ni}, 1 \sim 2 \% \mathrm{Mo})$ の再加熱に よる脆化曲線が KIEsSLING ${ }^{12)}$ によて発表されている. 


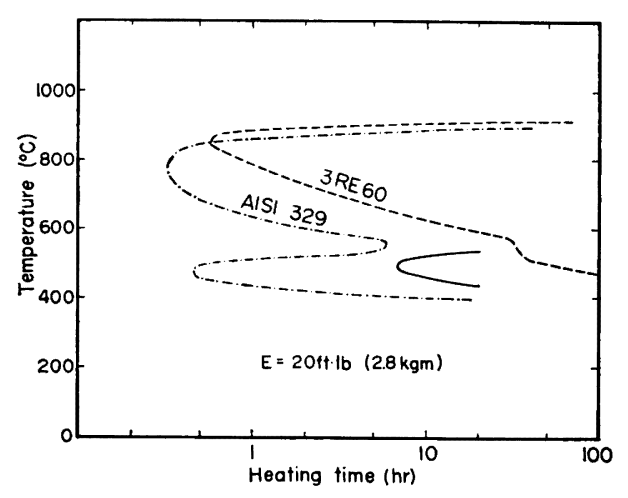

Fig. 5. Comparison of embrittlement behavior by reheating in various two phase stainless steels.

Fig. 5 に示した脆化曲線は吸収エネルギ $20 \mathrm{ft} \cdot \mathrm{lb}(2.8$ $\mathrm{kg} \cdot \mathrm{m})$ の等エネルギ曲線であるので, Fig. 4 より吸収エ ネルギが $2.8 \mathrm{~kg} \cdot \mathrm{m}\left(3.5 \mathrm{kgm} / \mathrm{cm}^{2}\right)$ となるに要する加熱 時間を求め, 試験温度 $0^{\circ} \mathrm{C}$ での結果を Fig. 5 に実線で 示した. Fig. 5 より明らかなことは, 上記実用 2 相ステ ンレス鋼では $475^{\circ} \mathrm{C}$ 脆性と $700 \sim 800^{\circ} \mathrm{C}$ にある $\sigma$ 相脆 性が顕著であり，炭窒化物による粒界脆性は余り問題と ならないことである。

$475^{\circ} \mathrm{C}$ 脆性に関しては, AISI 329 の等エネルギ曲線 が最も短時間側にあり，2 相分嚾反応による脆化速度が 大きいことを示し，ついで当実験合金となり，3RE60 は 最も長時間側に移行していた。 この 3RE60 の脆化感受 性の小さい理由として，化学分析結果の比較検討より第

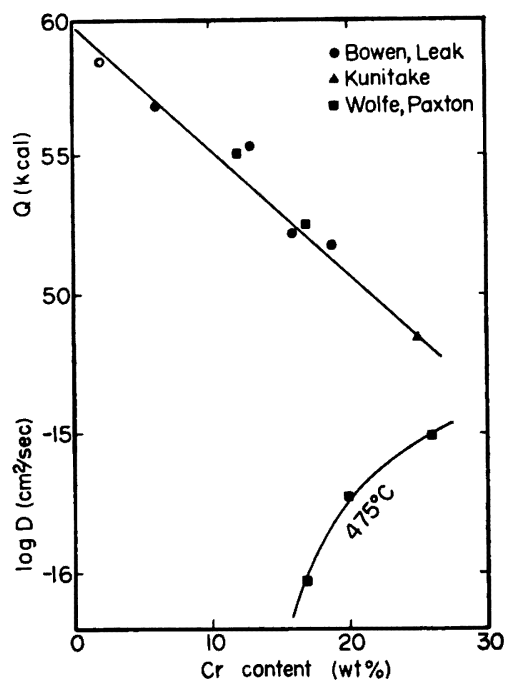

Fig. 6. Variation in activation energy $Q$ and diffusion coefficient $D$ with $\mathrm{Cr}$ content in $\mathrm{Fe}$ Cr alloy ${ }^{13)}$.
一に Cr 含有量の低いことが考えられる.

$475^{\circ} \mathrm{C}$ 脆性は 2 相分䜅による $\mathrm{Cr}$ rich 相の析出に基因 するので，この過程を律速するのはb.c.c.の Fe-Cr 合 金中での Cr の拡散速度であると予測される. BOWEN ${ }^{13)}$ によつて発表された $\mathrm{Fe}-\mathrm{Cr}$ 合金中の $\mathrm{Cr}$ の体積拡散に 関するデータを総括すると Fig. 6 の結果がもたらされ る.すなわち， $\mathrm{Fe}-\mathrm{Cr}$ 合金中の $\mathrm{Cr}$ の拡散のための活性 化エネルギ Q は， $30 \% \mathrm{Cr}$ までの範囲内では Cr 含有量 の増加につれて直線的に減少する. そのため $\mathrm{Fe}-\mathrm{Cr}$ 合 金中の $\mathrm{Cr}$ の拡散は $\mathrm{Cr}$ 量の増大とともに促進されるこ とになる. Fig. 6 に $475^{\circ} \mathrm{C}$ に打ける $\mathrm{Cr}$ の拡散係数の 変化 ${ }^{14)}$ を示したが，25\% Cr 合金中の $\mathrm{Cr}$ 拡散係数は $17 \% \mathrm{Cr}$ 合金に比較するこ1枌も異なつており，それだ け高 $\mathrm{Cr} フ ェ ラ イ ト$ 合金では $475^{\circ} \mathrm{C}$ 脆化感受性が大き (8)ことになる。

$475^{\circ} \mathrm{C}$ 脆性とともに $\sigma$ 相脆性も $\mathrm{Cr}$ 拡散によつて律速 されるという点では共通しているが，これらの反尤程 における合金元素の作用はそれぞれ異なつている．例え ば $475^{\circ} \mathrm{C}$ 脆性に対しては $\mathrm{Cr}$ および Mo はこれを促進 するが15)，Si や Mn の効果については疑問である.と こつが， $\sigma$ 相脆性に関しては $\mathrm{Cr} ， \mathrm{Mo}$ 以外に Si および Mn が強力な促進元素として知られており ${ }^{16)}$ ，これら促 進元素は昖散速度に対する初果よりも，平衝状態図にお いて $\sigma$ 相安定領域を低 $\mathrm{Cr}$ 側に移行させる効果が顕著で ある. $\sigma$ 相生成におよぼす合金元素の効果の中で，拡散 速度への効尖は第二義的であり，基本的要因は平衡状態 における $\sigma$ 相の安定性への効果であろう。ところが，合 金元素の昖散が顕著でない $475^{\circ} \mathrm{C}$ 領域では $\mathrm{Cr}$ の昖散速 度への効果が重要となる。

上述の仮説を利朋すれば, Fig. 5 における $475^{\circ} \mathrm{C}$ 脆化 は $\mathrm{Cr}$ と Mo 量によつて支配される結果 AISI329 にお いて最も短時間内に起こる。一方 $\sigma$ 相脆性においては $\mathrm{Cr}$ に加えてとくに Si，Mn，Moなどが律速元素となる ので，3RE60のような低 $\mathrm{Cr}$ 合金でも $\sigma$ 生成速度は大き く，本実験の供試材のような高純度合金ではその生成速 度が小さいものと考えられる。なお実朋鋼では $\mathrm{C}$ 量につ いても検討すべきであるので，これについては後述する。

\section{$3.4475^{\circ} \mathrm{C}$ 脆性におよぼす先行 $a \rightarrow r$ 変態の効果}

2 相ステンレス鋼の徐泠に際して生じる䩒性の低下は $475^{\circ} \mathrm{C}$ 脆性に基因するもので，高温域では $\sigma$ 相が生成し ないかぎり $\alpha \rightarrow \gamma$ 变態门体は靶性には何らの影響も与え なかつた。高温域より徐冷した場合，この $475^{\circ} \mathrm{C}$ 脆化 域に到達する以前に $\alpha \rightarrow \gamma$ 変態域を通過し， $\alpha-\gamma$ 変態 により $\gamma$ 量の増大とともに $\alpha$ 相中の $\mathrm{Cr}$ 量増加, $\mathrm{Ni}$ 量低 下が尘じることは前述のとおりである. 


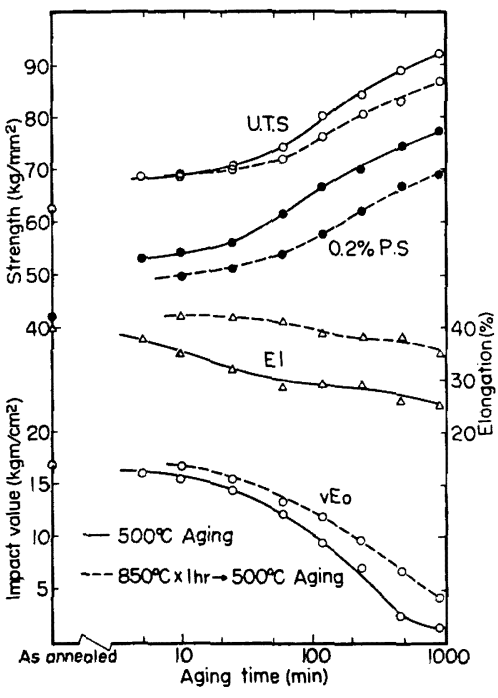

Fig. 7. Effect of austenite enrichment on the mechanical properties of aged materials.

2 相ステンレス鋼の $\gamma$ 相は応力緩和作用を有し ${ }^{8)}, \alpha$ 相中に生じた龟裂の伝播に対して抑制作用があるため, r相の存在は䩖性向上には好をしいものであるが，一方 $\alpha$ 相中の $\mathrm{Cr}$ 量増加は前述のように $475^{\circ} \mathrm{C}$ 脆化の促進 作用があり，また $\mathrm{Ni}$ 量低下も衝整遷移温度の上昇 ${ }^{17}$ を もたらし，鞂性には好ましくない。

これらの相反する作用が $475^{\circ} \mathrm{C}$ 時効した材料の機械 的性質におよぼす効果を検討するため， $850^{\circ} \mathrm{C} \times 1 \mathrm{~h}$ の 再加熱処理によつて $\gamma$ 量を $38 \%$ から $55 \%$ に増加後, 脆 化速度最大の $500^{\circ} \mathrm{C}$ に打いて時効処理して機械的性質 を比較検討した。

引張および衝慗試験の結果 をFig. 7 に示す.この場 合 $0.2 \%$ 耐力は $\alpha$ 量減少のために低下し，伸びは $\gamma$ 量增 加によつて増大した。 ところが，引張強さは $0.5 \mathrm{~h}$ 以下 の加熱では両供試材とも同程度であるが，1 $\mathrm{h}$ を超える と $\alpha$ 相の 2 相分離の奻果が現われる.これは時効初期に は 2 相分離による強さ上昇は小さく，r相の加工硬化の 影響が明白に現れるためと考えられる。

勒性に関しては， $475^{\circ} \mathrm{C}$ 脆性の結果としてシャルピー 衝撃值 $\left(V E_{0}\right)$ は徐々に低下するが，普通処理材に比較す ると, $\gamma$ 増加材では 2 倍の脆化時間を要し, 先行 $\alpha \rightarrow \gamma$
変態は $475^{\circ} \mathrm{C}$ 脆化感受性を軽減できることが明らかと なつた。

\section{$3.5 \sigma$ 相生成におよぼす $\mathbf{C}$ 量の効果}

前述のように実用 2 相ステンレス鋼では $\sigma$ 相脆性が現

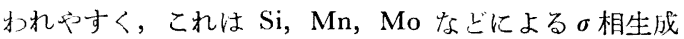
領域の拡大，すなわち， 考えてきた。しかし，従来のオーステナイトステンレス 鎆の研究において, $\sigma$ 相は $\mathrm{Cr}$ 炭化物 $\mathrm{Cr}_{23} \mathrm{C}_{6}$ を核とし

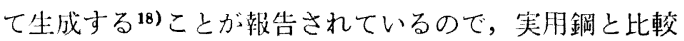
して C 量や炭化物の影響を検討することも必要であろ う. そこで今まで用いた低炭素合金のほか，実用鋼の $\mathbf{C}$ 量と同程度の $0.03 \% \mathrm{C}$ を含む 3 種の比較合金を用いて 検討した. これら試料の化学組成を Table 3 に示す. ここで $\mathrm{C} 1$ 合金は $\mathrm{C}$ 量もしくは炭化物の核生成効果を調 ベるものであり，また C2 合金は $\alpha$ 相中の Cr 濃度を高 め, $\mathrm{C} 3$ 合金は $\mathrm{Ti}$ 添加によつて $\mathrm{Cr}_{23} \mathrm{C}_{6}$ を $\mathrm{TiC}$ に置換 し，それぞれ $\mathrm{Cr}$ 濃度と $\mathrm{TiC}$ の効果を調べるものであ る.

4 種類の合金を $700^{\circ} \mathrm{C} \times 96 \mathrm{~h}$ までの再加熱後水冷し, 加熱時間にともなうシャルピー衝揧值の変化を調べると Fig. 8 の結果が得られた. 前述の $8 \mathrm{~h}$ な゙の加熱では $\sigma$ 相が生成しなかつた低炭素合金も長時間後には $\sigma$ 相生成 のために衝整値の急激な降下が現われた. 予期に反して， C 量の高い CI 合金の $\sigma$ 相生成による衝揧値の低下は高 純度の低炭素合金での結果と類似しており，そのため炭 化物 $\mathrm{Cr}_{23} \mathrm{G}_{6}$ が $\sigma$ 相生成の核として作用するというオー

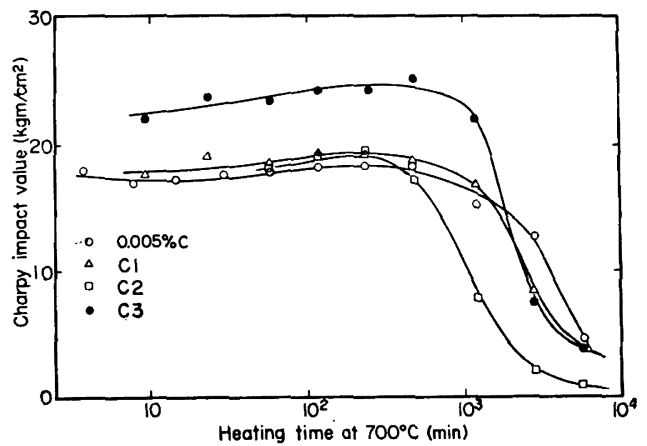

Fig. 8. Variation in notch-toughness with heating time at $700^{\circ} \mathrm{C}$.

Table 3. Chemical composition of the carbon-bearing alloys (wt \%).

\begin{tabular}{c|c|c|c|c|c|c|c|c|c|c}
\hline & $\mathrm{G}$ & $\mathrm{Gr}$ & $\mathrm{Ni}$ & $\mathrm{Si}$ & $\mathrm{Mn}$ & $\mathrm{S}$ & $\mathrm{P}$ & $\mathrm{Ti}$ & $\mathrm{AJ}$ & $\mathrm{N}$ \\
\hline $\mathrm{G} 1$ & 0.037 & 24.83 & 6.09 & 0.015 & 0.004 & 0.012 & 0.003 & 0.010 & 0.001 & 0.0103 \\
C2 & 0.039 & 25.53 & 6.40 & 0.014 & 0.009 & 0.012 & 0.003 & 0.009 & 0.001 & 0.0094 \\
G3 & 0.034 & 24.66 & 5.81 & 0.010 & 0.007 & 0.011 & 0.002 & 0.090 & 0.009 & 0.0087 \\
\hline
\end{tabular}




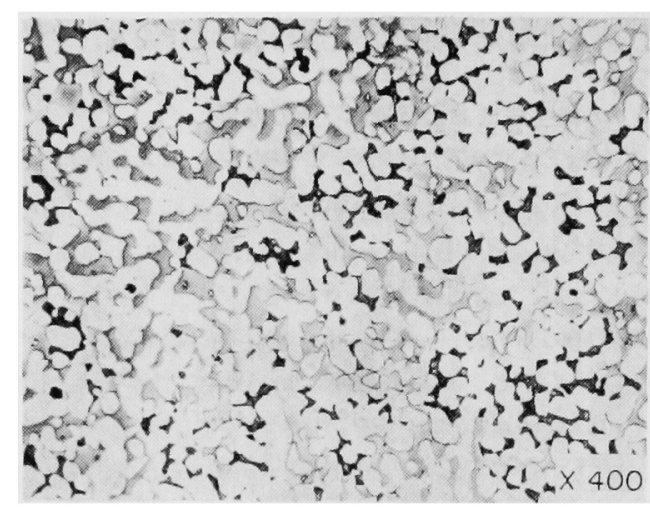

Photo. 4. Formation of $\sigma$ phase by decomposition of $\alpha$ into $\sigma+\gamma$ in alloy C2 heated at $700^{\circ} \mathrm{C}$ (Etched by Murakami's reagent).

ステナイト合金での結果は 2 相ステンレス鋼には適用で きず，また Ti 添加合金 (G3) での挙動からも同じ結論 が導かれる。

以上のように, $\mathrm{C}$ 量もしくは炭化物が $\sigma$ 相生成には無 関係であることが明らかとなつたが，Cr 量の若千高い C2 合金は他の 3 合金に比較して短時間側で $\sigma$ 相脆化が 生じた.この結果は 2 相ステンレス鋼中の $\sigma$ 相生成が炭 化物の存在と関係なく, Photo. 4 に示すように高ク口 ム・フェライト相(灰色)の $\sigma$ 相 (黑色) と $r$ 相(白色)への 分解によることを示唆している.

このように 2 相ステンレス鋼の $\boldsymbol{\sigma}$ 相生成においては高 Cr の $\alpha$ 相の分解過程を通る方が活性化自由エネルギの 点で有利であるが，これは高 Cr $の \alpha$ 相中では前述のよ うに Gr の拡散が容易でありまた Fe-Cr 状態図到の $\alpha / \alpha+\sigma$ 境界に近い組成に Cr 濃度が達しているためで ある。

$\sigma$ 相生成には Cr 量の影響がとくに重要であるが，一 方実用合金における Si，Mn，Mo の存在は前述のよう に, $\alpha+\gamma / \alpha+\gamma+\sigma$ の境界を低 $\mathrm{Cr}$ 側一移行して $\sigma$ 相生 成を容易にすると考えられる19).

この $\sigma$ 相生成反応は, 前述の $475^{\circ} \mathrm{C}$ 時効とは異なつ て，潜伏期の存在することが Fig. 8 からも明らかであ る.しかし $\sigma$ 相が微量析出すると直ちにシャルピー衝慗 值は急激に降下寸る。 $\sigma$ 相生成の初期段階における硬さ の上昇上靶性の低下の対応性は良好でなく, BUNGARDT 20)の結果によれば $\sigma$ 相が $5 \%$ 以上生成してはじめて硬さ 上昇が始まるとされている. Photo. 5 は $700^{\circ} \mathrm{C} \times 96 \mathrm{~h}$ 加 熱後の $\sigma$ 相生成の椂相を示すもので, $5 \mathrm{a}$ での $\sigma$ 相の量 は 5\% に満たないが Fig. 8 では著しい衙撃値の低下が 生じ,この場合硬さの変化は検出されなかつた.一一方 $5 \mathrm{~b}$ の $\mathrm{Cr}$ 量の若干高い $\mathrm{C} 2$ 合金においては多量の $\sigma$ 相の生
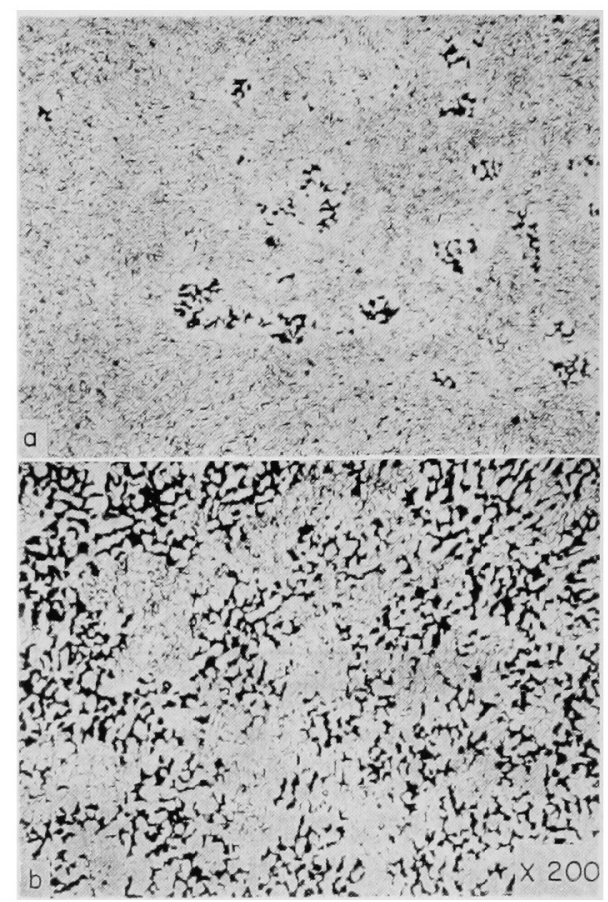

(a) high purity alloy

(b) alloy $\mathrm{C2}$

Photo. 5. Distribution of $\sigma$ phase after heating at $700^{\circ} \mathrm{C}$ for $96 \mathrm{~h}$

成によつて Hv20 程度の上昇が現れるが，この状態では 衝揧值はすでにに0なつており。相の生成した試料につ いては衝揧值の組織敏感性に比べて硬さの非敏感性が明 白である。

\section{4. 結言}

25Cr-6Ni 2 相ステンレス鋼の再加熱による機械的性 質の变化について研究し，その結果を総括すると次の通 りである.

（1） $1000^{\circ} \mathrm{C}$ 焼なまし水冷後, $475 \sim 525^{\circ} \mathrm{C}$ で再加 熱すると 2 相分離のために $0.2 \%$ 耐力および引張強さは 上昇し, 一方伸びは低下した。絞りは時効時間 $16 \mathrm{~h}$ まで は 60〜70\%の值を示した.これは時効時間にともなう 伸びの低下は均一伸びの低下であり，局部伸びの变化が 少ないことに対応している.

（2） $650 \sim 800^{\circ} \mathrm{C}$ で再加熱すると， $\alpha \rightarrow \gamma$ 変態が生 じ, $0.2 \%$ 耐力は $\alpha$ 量に比例して变化する傾向があつた. 一方引張強さには $\gamma$ 相の加工硬化の寄与が大きく現われ た.

（3）シャルピー衝揧試験の結果， $475^{\circ} \mathrm{G}$ 時効によつ て衝撃值の著しい低下が現われた．これは $475^{\circ} \mathrm{C}$ 脆化 による遷移温度の上昇に基づくものである. 一方 $\alpha \rightarrow \gamma$ 
変態による衝撃值の変化は全く現われなかつた。

（4） $475^{\circ} \mathrm{C}$ 脆化におよぼす先行 $\alpha \rightarrow \gamma$ 変態の効果を 知るため， $\gamma$ 増加材の脆化挙動を調べたところ， $\gamma$ 相の 増加によつて $0.2 \%$ 耐力は低下するが， $475^{\circ} \mathrm{C}$ 脆化感受 性の軽減作用が認められた。

（5）各種実用鋼の再加熱による脆化挙動を比較した ところ, $475^{\circ} \mathrm{C}$ 脆性は $\alpha$ 相中の $\mathrm{Cr}$ 量によつて律速され ると考えられる. 一方 $\sigma$ 相脆性には $\mathrm{Cr}$ 量以外に $\mathrm{Si}$, Mn，Mo の効果が重要であると推察された.

2 相ステンレス鋼での $\sigma$ 相生成は $\mathrm{Cr}$ 炭化物の存在に よつて促進されるものでなく，むしろ $\alpha$ 相中の $\mathrm{Cr}$ 量が 重要であり，この $\alpha$ 相の分解によつて $\sigma$ 相が現れた.

終りに，本実験に協力して頂いた山口英雄（現在 日 本高周波）扎よび桑島正尚（現在 日本電工）の両氏に 謝意を表します。

\section{文献}

1) H. W. Hayden, S. Floreen: Met. Trans., 1 (1970), p. 1955

2 ) 鈴木隆志, 長谷川博一, 渡辺三雄: 日本金曆学会 誌, 32 (1968), p. 1175

3) D. M. WARD: Iron steel, (1970), p. 11

$4)$ 藤倉正国, 阿部直弘: 電気製鋼, 45 (1974) 2, p. 73
5 ) R. O. Williams: Trans. AIME, 212 (1958), p. 497

6) 河部義邦, 金尾正雄, 宗木政一：鉄と鋼，59 (1973), p. 1388

7 ) P. Jol.ly, J. Hochmann: Mem. Sci. Rev. Met., 70 (1973), p. 117

$8) S$. Floreen, $H . W$. Hayden: Trans. ASM, 61 (1968), p. 489

9) 田村今男, 友田陽, 他：鉄之鋼，59(1973), p. 454

10) W. O. Binder, H. R. Spendelow: Trans. ASM, 43 (1951), p. 759

11) H. $W$. Hayden, S. Floreen: Trans. ASM, 61 (1968), p. 474

12) R. Kiessling: Scand. J. Met., 1 (1973), p. 459

13) A. $W$. Bowen, G. M. Leak: Met. Trans., 1 (1970), p. 1695

14) R.J. Hodges: Corrosion, 27 (I971), p. 119

15) P.J. Grobner: Met. Trans., 4 (1973), p. 251

16）熊田健三郎：日本金属学会報, 2 (1963)，p. 261

17) 岡田秀弥, 細井祐三, 小川洋之: 鉄と鋼, 59 (1973), S 155

18) W. Koch, et al.: Stahl u Eisen, 78 (1958), p. 1251

19) $F . J$. Shortsleeve, M. E. Nicholson: Trans. ASM, 41 (1950), p. 142

20) K. Bungardt, et al.: Arch. Eisenhuttenw., 34 (1963), p. 465 